\title{
GY II represses proliferation and metastasis and promotes apoptosis in laryngeal squamous cell carcinoma
}

\author{
Yunfei Bai ${ }^{1}$, Ru Wang ${ }^{1}$, Xiaobo Cui ${ }^{2}$, Lin Feng ${ }^{1}$, Qian Shi ${ }^{1}$, Hongzhi Ma ${ }^{1}$, Meng Lian ${ }^{1}$, Xixi Shen ${ }^{1}$, Yifan Yang ${ }^{1}$, Chen Tan ${ }^{1}$ and Jugao Fang $^{1 *}$ \\ ${ }^{1}$ Department of Otorhinolaryngology Head and Neck Surgery, Beijing Tongren Hospital, Capital Medical University, China \\ ${ }^{2}$ Department of Otorhinolaryngology, Inner Mongolia Medical University Affiliated Hospital, China
}

\begin{abstract}
Background: Traditional Chinese medicine (TCM) is considered to have some superiorities in treatment of cancer and Guben Yiliu II (GY II) has been widely used for clinical treatment of cancer in China.

Aims/objectives: To investigate the effects of GY II on the proliferation, apoptosis, invasion and metastasis of laryngeal squamous cell carcinoma.

Material and methods: The effects were detected via MTT, Transwell assay and Flow Cytometry, respectively in Hep-2 and cells from clinical samples. Microarray analysis was conducted to identify which genes and pathway were involved in laryngeal squamous cell carcinoma development.

Results: Result of MTT assay revealed that GY II inhibited the growth of cells via arresting the cell cycle at G0/G1 phase. The addition of GY II significantly suppressed cell migration and invasion. Meanwhile, GY II treatment also significantly promoted apoptosis of tumor cells. Microarray result indicated genes were associated with cancer cell development.
\end{abstract}

Conclusions and significance: GY II was able to suppress cell development and promote cell apoptosis in laryngeal squamous cell carcinoma. Our findings have significant implications regarding understanding the mechanism and target of TCM herb GYII in term of tumor cure

\section{Introduction}

Laryngeal carcinoma is the second-most common type of head and neck cancer, and the prevalence of laryngeal cancer is as high as 72.7 per 100,000 individuals [1]. In clinical treatment, the main treatments for laryngeal cancer include surgery, radiotherapy and chemotherapy. Malnutrition of patients, which are usually due to surgical trauma, immune suppression caused by chemotherapy drugs, inadequate nutrients intake, metabolic disorders and the high metabolic status caused by the disease, seriously deteriorate the treatment and prognosis of the cancer [2]. In contrast, Traditional Chinese medicine (TCM) is considered to have some superiorities in treatment of cancer, some active compounds have been isolated from TCM and regarded as valuable drugs for anti-cancer [3]. For example, $\beta$-elemene, a compound isolated from Curcuma, is used as an anti-cancer drug in China $[4,5]$. According to the theory of TCM, laryngeal carcinoma is caused by stagnation of blood and phlegm which are resulted from the deficiency of Zang-Fu organs [6]. In fact, cancer suffers, especially in late stage, did generally have symptoms with blood stagnation and/ or blood stagnation in Qi deficiency condition. For the treatment, Qi should be strengthened to protect the body and activate blood to eliminate pathogenic factors, and therefore to reestablish a new balance [7].

In recent days, for patients with Chinese backgrounds, Chinese Herbal Medicine (CHM) tends to be the most popular type among cancer patients and are wildly used to reduce the adverse events (AEs), enhance the body's immunity and the quality of life, prevent metastasis and also applied in adjuvant treatment during chemo-andradiotherapy. Furthermore, $\mathrm{CHM}$ is used as an alternative treatment for cancers, including breast cancer, lung cancer and pancreatic cancer [8].
Guben Yiliu II (GY II), created by Rencun Yu and other masters majoring in TCM, is an important component which could promote the synthesis of benefiting Qi for activating blood circulation and detoxifying and a prescription wildly used in china. Based on the clinical experiences, accumulative clinical trials demonstrate the anticancer property of GY II [9].

In order to explore the antitumor functions of GY II and the possible mechanisms, we detected the influences of GY II-containing serum from mice on the function of Hep- 2 cell and primary human laryngeal carcinoma cell.

\section{Materials and methods}

\section{Cell culture}

Hep-2 cell line was purchased from China Center for Type Culture Collection (CCTCC) of Wuhan University. The primary laryngeal cancer cells were isolated from laryngeal cancer tissues of patients. The informed consent was obtained and approved by the Ethics Committee of Beijing Tongren Hospital. All the cells were cultured in fresh PRMI1640 (gibco) medium supplemented with 10\% fetal bovine serum

${ }^{*}$ Correspondence to: Jugao Fang, Department of Otorhinolaryngology Head and Neck Surgery, Beijing Tongren Hospital, Capital Medical University, Beijing, China, Tel: 86-01058269206; E-mail: fangjg19651110@163.com

Key words: Guben Yiliu II (GY II), laryngeal squamous cell carcinoma, traditional chinese medicine (TCM).

Received: December 03, 2018; Accepted: December 22, 2018; Published: December 26, 2018 
(FBS, HyClone) in an incubator (Thermo) with $5 \% \mathrm{CO}_{2}$ at $37^{\circ} \mathrm{C}$. The cells were sub cultured once $90 \%$ cells were fused.

\section{Preparation of GY II aqueous extract}

GY II was obtained from Beijing Hospital of Traditional Chinese Medicine, and was extracted from 13 different species of herbs used in TCM, including Codonopsis, Poria, Atractylodes, Radix Astragali, Rhizoma Chuanxiong, Caulis Spatholobi etc. According to the requirements of the current study, $7.88 \mathrm{Kg}$ raw materials in total produced $250 \mathrm{~g}$ of clear ointment contained $2.42 \mathrm{~g}$ crude drug (GY II). The products of extraction were stored in $-80^{\circ} \mathrm{C}$.

\section{Preparation of GY II-containing serum}

30 male Wistar rats with body weight of 180 190 g, were purchased from Vital-Lee Company. The rats were fed with standard laboratory food and water in individual cages. 30 rats were randomly divided into two groups, 20 of which as experimental group were performed to lavage using GY II and 10 of which as control group were performed to lavage using normal saline, respectively. For GY II treatment, the dosage was $20 \mathrm{~g}$ crude drug per $\mathrm{Kg}$ body weight of rats and each rat was given two times a day for six days. After the last treatment, the rats were sacrificed to collect blood from the abdominal aorta. After $2 \mathrm{~h}$ incubation in room temperature, the blood was centrifuged for $20 \mathrm{~min}$, $3500 \mathrm{r} / \mathrm{min}$ and serum was obtained followed incubation at $56^{\circ} \mathrm{C}$ for $30 \mathrm{~min}$ to induce inactive. Then the serum was diluted with cell culture medium before application. All animal experiments were approved by the Animal Use and Management Committee of University.

\section{MTT assay}

The viability of Hep-2 cells and primary laryngeal carcinoma cells was determined by methyl thiazolyl terazolium (MTT) assay. Hep-2 cells or primary laryngeal carcinoma cells were seeded into 96-well plates at a density of 5000 cells/well incubated overnight until cells were adherent, and then exposed to various concentrations of GY IIcontaining serum $(0 \%, 25 \%, 50 \%, 75 \%$ and $100 \%)$ for $24 \mathrm{~h}$. The cell proliferation in each group was detected using MTT kits (E606334, Sangon Biotech). After adding MTT solution in an amount of $10 \%$ of the culture medium, the cells were cultured for $4 \mathrm{~h}$. After removal of the solution, $200 \mathrm{ul}$ DMSO was added into each well with a $10 \mathrm{~min}$ oscillation to completely dissolve the formazan crystals. The absorbance of each well at $\mathrm{OD}_{540}$ was measured for calculating the cell inhibitory rate and $\mathrm{IC}_{50}$. Three repeated wells were set for each group, and the experiment was repeated independently for 3 times.

\section{Cell invasion assay}

Cell invasion assay was performed in 24-well transwell chambers containing polycarbonate membrane with $10 \mathrm{~mm}$ diameter and $8 \mathrm{um}$ pore. In brief, Matrigel (Corning, 354248) was firstly diluted with incomplete culture medium and then $60 \mu \mathrm{l}$ dilution was added to each Transwell upper chamber, $5 \times 10^{4}$ Cells in $200 \mathrm{ul}$ of GY II-containing serum were seeded into the upper chamber, the lower chamber was filled with $500 \mathrm{ul}$ of preheated medium containing $10 \%$ FBS. After $16 \mathrm{~h}$ incubation at $37^{\circ} \mathrm{C}$, the cells were fixed with $4 \%$ paraformaldehyde for $10 \mathrm{~min}$. The non-invasive cells were removed with cotton swab, and the upper chamber was washed with PBS two times, the number of cells that have invaded through the basement membrane were counted following staining with $0.2 \%$ crystal violet $/ 20 \%$ methanol (wt/vol) solution for 15 $\mathrm{min}$. The invaded cells were visualized under microscope and averaged in three random fields at a magnification of 10x.

\section{Cell migration assay}

Cell migration assay was performed in 24-well transwell chamber (Corning, 3458) with $10 \mathrm{~mm}$ diameter and 8 um pore according to the manufacturer's instructions. Briefly, cells were resuspended in $200 \mathrm{ul} \mathrm{GY} \mathrm{II-containing} \mathrm{serum} \mathrm{and} \mathrm{seeded} \mathrm{into} \mathrm{the} \mathrm{upper} \mathrm{chamber.}$ Meanwhile, $500 \mathrm{ul}$ of medium containing $10 \% \mathrm{FBS}$ was added into the lower chamber. After $16 \mathrm{~h}$ incubation at $37^{\circ} \mathrm{C}$, migrated cells were dyed with $0.2 \%$ crystal violet $/ 20 \%$ methanol (wt/vol) solution for $15 \mathrm{~min}$ and counted under microscope, three fields of view were randomly selected for each chamber.

\section{Flow cytometry for analysis of apoptosis and cell cycle}

For apoptosis analysis, the cells $\left(5 \times 10^{5}\right.$ cells/well $)$ were seeded in 6-well plates and treated with GY II-containing serum for $24 \mathrm{~h}$ and then digested by trypsin without EDTA. Cells were transferred to micro-centrifuge tubes and washed twice with PBS. According to the manufacturer's instructions, cells were re-suspended with $500 \mathrm{ul}$ binding buffer and subsequently incubated with $5 \mathrm{ul}$ Annexin V-FITC and $5 \mathrm{ul}$ PI solution for $5 \mathrm{~min}$. The percentage of apoptotic cells was analyzed by flow cytometry.

For cell cycle analysis, cell suspension was mixed with PBS (according to the concentration of drug), and fixed in $70 \%$ ethanol at $4^{\circ} \mathrm{C}$ overnight. After overnight incubation at $4^{\circ} \mathrm{C}$, the immobilized cells were collected by centrifugation and suspended in PBS followed with PI staining for $30 \mathrm{~min}$. Cellular DNA content of each phase was quantified by flow cytometry.

\section{Data statistics and processing}

The significance of the data was analyzed by the using of SPSS 20.0 statistical software. All the data were presented as mean \pm standard deviation $(\mathrm{x} \pm \mathrm{s}$ ). The unpaired student's $t$-test was applied for comparison between two groups and one-way or two-way ANOVA was used for comparison among groups. Statistical significance was set as $\mathrm{P}<0.05$.

\section{Results}

GY II inhibited the growth of Hep-2 and primary laryngeal carcinoma cells

To investigate the effects of GY II on tumor cell growth, MTT assays was performed to calculate the proliferation rate. As shown in table 1 and figure 1, GY II-containing group significantly repressed the proliferation of primary laryngeal cancer cells and Hep-2 cells, and furthermore the repression effects displayed in a dose-dependent manner (Figure 1). The inhibitory rate and IC50 respectively was $54.4 \%$ and $67.59 \mathrm{mg} / \mathrm{ml}$ in primary laryngeal cancer cells when the concentration of added GY II-containing serum is $75 \%$ (Figure 1 and Table 1). Meanwhile, it displayed 55.3\% inhibitory rate and $69.57 \mathrm{mg} /$ $\mathrm{ml} \mathrm{IC}_{50}$ when concentration of added GY II-containing serum is $75 \%$ in Hep-2 cells (Figure 1 and Table 1).

\section{GY II prevented laryngeal carcinoma cell migration and invasion}

Invasion and metastasis were important features of the tumor. Therefore, the effects of GYII on invasion and metastasis of laryngeal carcinoma cell and Hep-2 cell were further analyzed using Transwell migration assay. After addition of GYII in the serum, the number of cells passing through the filter membrane in the lower chamber was reduced in both Hep- 2 cells and primary laryngeal carcinoma cells. It 


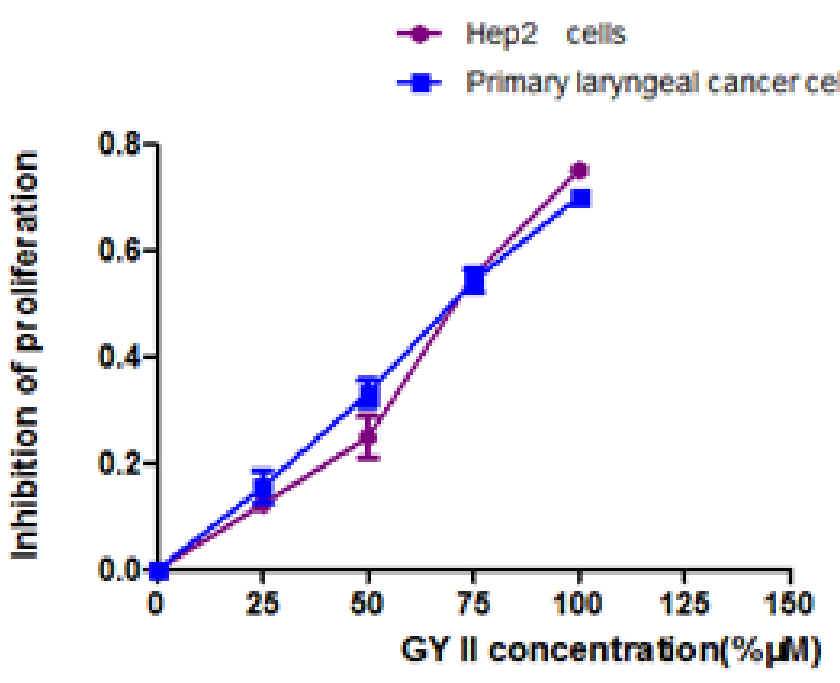

Figure 1. Effects of GY II on primary laryngeal carcinoma cells and Hep-2 cells proliferation in vitro. MTT assays were performed to determine the proliferation of cells

Table 1. Inhibitory rates of primary laryngeal carcinoma cells and Hep-2 cells $(\%)(\overline{\mathrm{x}} \pm \mathrm{s})$. Compared with the control group, ${ }^{*} P<0.05,{ }^{\#} P<0.001$

\begin{tabular}{|c|c|c|}
\hline $\begin{array}{c}\text { Drug concentration } \\
(\boldsymbol{\mu M})\end{array}$ & $\begin{array}{c}\mathbf{I C}_{\mathbf{5 0}} \text { (primary laryngeal } \\
\text { carcinoma cells) }\end{array}$ & $\mathbf{I C}_{\mathbf{5 0}}$ (Hep-2 cells) \\
\hline Control group $(0 \%)$ & 1 & 1 \\
\hline $25 \%$ & $15.5 \pm 5.4^{*}$ & $12.3 \pm 0.9^{*}$ \\
\hline $50 \%$ & $33.2 \pm 4.2^{\#}$ & $25.0 \pm 5.6^{\#}$ \\
\hline $75 \%$ & $54.4 \pm 3.8^{\#}$ & $55.3 \pm 1.1^{\#}$ \\
\hline $100 \%$ & $70.1 \pm 1.1^{\#}$ & $75.1 \pm 2.6^{\#}$ \\
\hline$F$ & 194.23 & 275.48 \\
\hline$P$ & $<0.0001$ & $<0.001$ \\
\hline
\end{tabular}

was further found that the results were displayed in a dose-dependent manner (Figure $2 \mathrm{~A}$ and $2 \mathrm{C}$ ). Besides, the invasion assay was also performed, and results were consistent with those in migration assay (Figure 2B and 2D). The above results indicated that GYII addition was able to inhibit cell migration and invasion.

\section{GY II promoted Hep-2 cell and primary laryngeal carcinoma} cell apoptosis

To determine the effect of GYII on apoptosis of Hep-2 cell and primary laryngeal carcinoma cell, the apoptotic cells were stained with Annexin V-fluorescein isothiocyanate (FITC), and the apoptosis rate of GYII-containing group was significantly higher than those of control group in Hep-2 cell (Figure 3 and Table 2). The results were consistent in primary laryngeal carcinoma cell (Figure 4 and Table2). The evidence indicated that the addition of GYII could induce the apoptosis of human laryngeal carcinoma Hep-2 cell line and primary laryngeal carcinoma cell.

\section{GY II affected Hep-2 cell and primary laryngeal carcinoma cell cycle}

To further investigate the mechanism of GY II in inhibiting the proliferation of cancer cells, cell cycle was further detected via flow cytometry. Intriguingly, the addition of GY II-containing serum exhibited great influences on cell cycle. GY II treatment dramatically caused G0/G1 phase arrest in Hep-2 and primary laryngeal carcinoma cells (Figures 5 and 6 and Table 3). Our results suggested that GY II treatment could inhibit cell proliferation via arresting tumor cells at G0/G1 phase.

\section{Discussion}

In theory of Traditional Chinese medicine, malignant tumor is considered to be in the category of "accumulation", of which the onset is deficiency of the vital-Qi [10].The imbalance of Yin and Yang Qi, further developed from pathological products, such as stagnation of Qi and blood stasis, phlegm, poison accumulate, are latent in vivo . In the view of TCM, the common approaches applied in the treatment of malignant tumors, such as chemotherapy and radiation, can damage healthy tendency and also elevate deficiency of Qi and blood stasis [11,12]. Fuzheng Peiben therapy in clinical treatment of TCM is often utilized to promote blood circulation in order to remove blood stasis to eventually mitigate the side effects of radiotherapy and chemotherapy and lengthen the patient's cycle of treatment [13]. Based on the principles of supplementing Qi, activating blood circulation and detoxification, GY II is a critical component of a long-term and wildly used prescription for treating Qi deficiency, blood stasis and toxin accumulation in cancer patients [14].

Guben Yiliu was rich in Astragalus, angelica, bighead atractylodes rhizome, Chinese yam, Poria and sub erect. Yam can notify the kidney to arrest spontaneous emission, and Chinese Angelica, prepared rehmannia root, Caulis Spatholobi can nourish blood and nourish yin [15]. Chinese angelica is the most useful component for supplementing blood and it can complement blood without leaving blood stasis and invigorate the circulation of blood at the same time. Zedoary turmeric, trigone and Corydalis can relieve pain. Notably, modern pharmacology studies confirm that curcuma zedoary, angelica, and Astragalus mongholicus can improve human immunity and even kill tumor cells [16].

Although TCM has been used for thousands of years, the underlying mechanisms are not well understood. Certain herbs are able to inhibit the migration and invasion of cancer cells in vitro, while others trigger apoptosis in cancer cells [17]. In our previous studies, the combination of chemotherapy and GYII displayed good short- and long-term effects, including improving the life quality of patients receiving chemotherapy via reducing the toxic and side effects of chemotherapy, and furthermore impairing the occurrence of Qi deficiency and blood stasis syndrome [18]. Our current study shows that GY II have a certain inhibitory effect on the migration and invasion of the primary laryngeal

Table 2. Apoptosis index of primary laryngeal carcinoma cells and Hep-2 cells $(\overline{\mathrm{x}} \pm \mathrm{s})$. Compared with the control group, ${ }^{*} P<0.05,{ }^{\#} P<0.001$

\begin{tabular}{|c|c|c|}
\hline $\begin{array}{c}\text { Drug concentration } \\
(\boldsymbol{\mu M})\end{array}$ & $\begin{array}{c}\text { Primary laryngeal } \\
\text { carcinoma cells } \mathbf{( \% )}\end{array}$ & Hep-2 cells (\%) \\
\hline Control group $(0 \%)$ & $2.41 \pm 3.32$ & $0.57 \pm 0.14$ \\
\hline $25 \%$ & $6.31 \pm 0.41^{\#}$ & $10.43 \pm 0^{*}$ \\
\hline $50 \%$ & $12.8 \pm 0.18^{\#}$ & $15.46 \pm 5.04^{*}$ \\
\hline $100 \%$ & $9.83 \pm 7.64^{\#}$ & $25.98 \pm 0.92^{*}$ \\
\hline$F$ & 34.05 & 577.21 \\
\hline$p$ & 0.03 & $<0.001$ \\
\hline
\end{tabular}

Table 3. Effect of serum containing GY II on Hep-2 cells cycle and primary laryngeal carcinoma cells. $(\mathrm{N}=3, \overline{\mathrm{X}} \pm \mathrm{S})$. ": Compared with the control group, $p<0.05$

\begin{tabular}{|c|c|c|c|c|c|}
\hline & & G0/G1 & $\mathbf{S}$ & G2/M & PI \\
\hline \multirow{4}{*}{$\begin{array}{c}\text { Primary } \\
\text { laryngeal } \\
\text { carcinoma }\end{array}$} & $0 \%$ (Control) & $27.11 \pm 2.07$ & $48.80 \pm 1.89$ & $18.38 \pm 0.47$ & $80.50 \%$ \\
\hline & $25 \%$ & $36.10 \pm 1.70^{*}$ & $46.37 \pm 3.45$ & $14.98 \pm 1.71$ & $84.63 \%$ \\
\hline & $50 \%$ & $69.08 \pm 2.11^{*}$ & $19.75 \pm 1.91^{*}$ & $1.40 \pm 2.33^{*}$ & $98.45 \%$ \\
\hline & $100 \%$ & $71.35 \pm 2.14^{*}$ & $13.33 \pm 1.02^{*}$ & $1.85 \pm 1.27^{*}$ & $97.86 \%$ \\
\hline \multirow{4}{*}{ Hep- 2 cells } & $0 \%$ (Control) & $25.80 \pm 2.87$ & $49.85 \pm 2.23$ & $18.23 \pm 1.03$ & $80.58 \%$ \\
\hline & $25 \%$ & $36.60 \pm 2.30^{*}$ & $46.10 \pm 3.23$ & $14.99 \pm 1.34$ & $84.66 \%$ \\
\hline & $50 \%$ & $65.80 \pm 2.21^{*}$ & $23.67 \pm 2.98^{*}$ & $3.90 \pm 2.23^{*}$ & $95.82 \%$ \\
\hline & $100 \%$ & $71.66 \pm 3.72^{*}$ & $12.98 \pm 2.11^{*}$ & $1.40 \pm 3.12^{*}$ & $98.37 \%$ \\
\hline
\end{tabular}




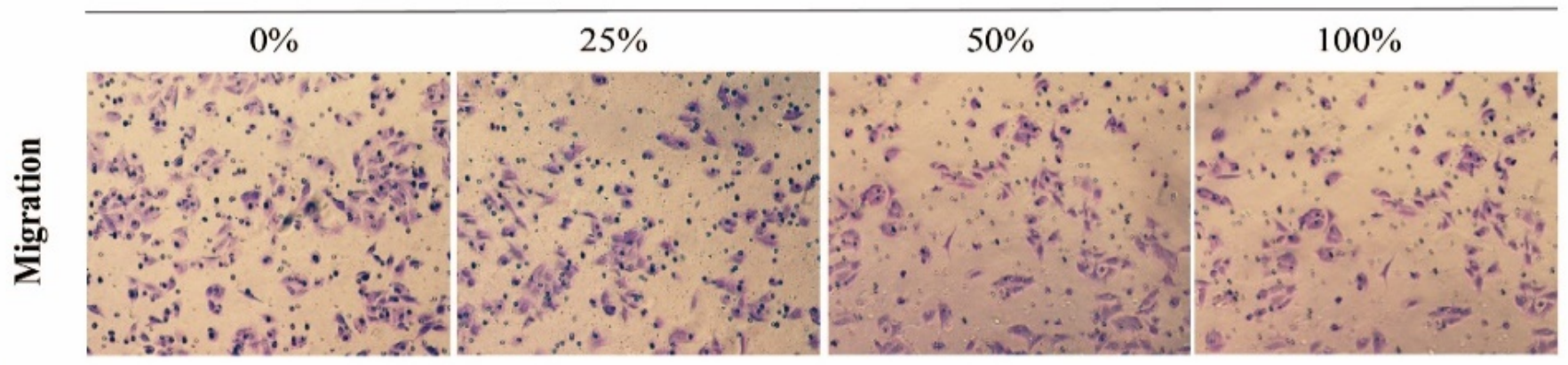

$\mathrm{B}$
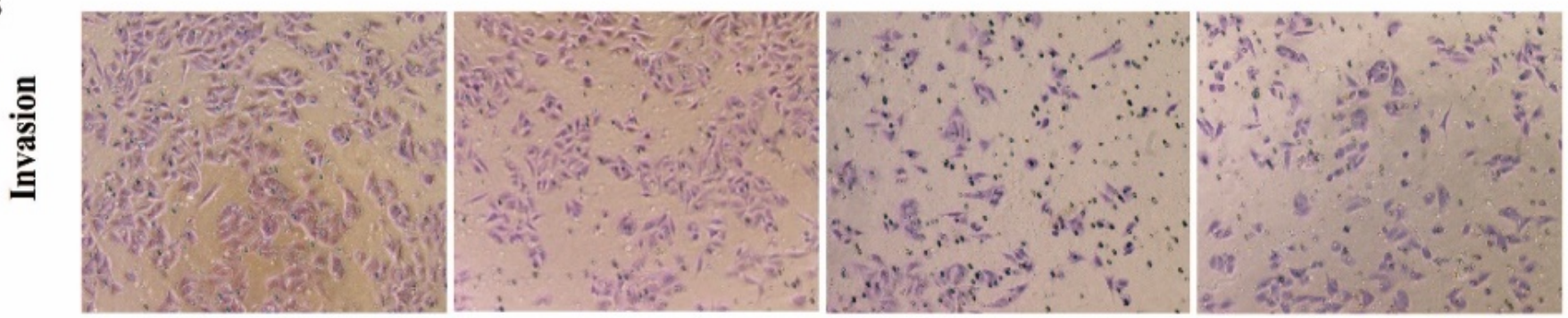

$\mathrm{C}$

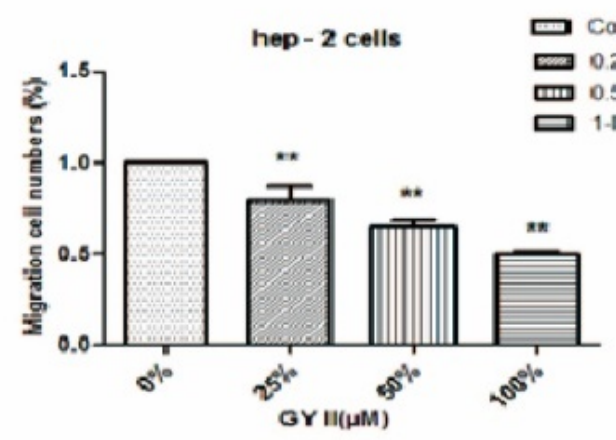

$\mathrm{D}$

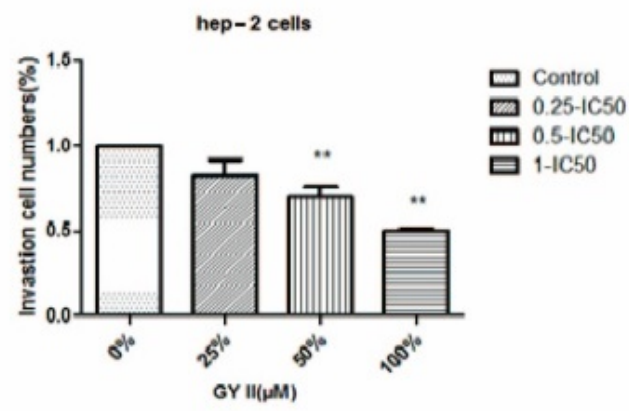

primary laryngeal carcinoma cells

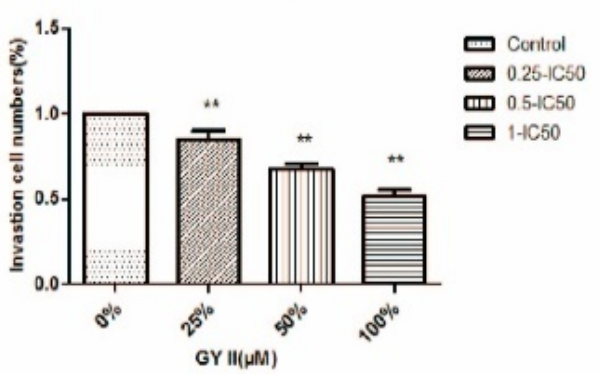

Figure 2. GY II attenuates cell migration and invasive. (A) Migration of Primary laryngeal carcinoma cells and Hep-2 cells were assayed for indicated time by transwell assay in the presence of different concentration of GY II-containing serum. (B) Invasion of Primary laryngeal carcinoma cells and Hep-2 cells were assayed for indicated time by matrigen transwell assay in the presence in the presence of different concentration of GY II-containing serum. (C-D) The statistical graphs of relative cell migration and invasion changes of results were showed. . All the data are presented as means $\pm \mathrm{SD}$ of 3 independent experiments. ${ }^{* *} \mathrm{p}<0.01$ by one-way ANOVA vs untreated control 

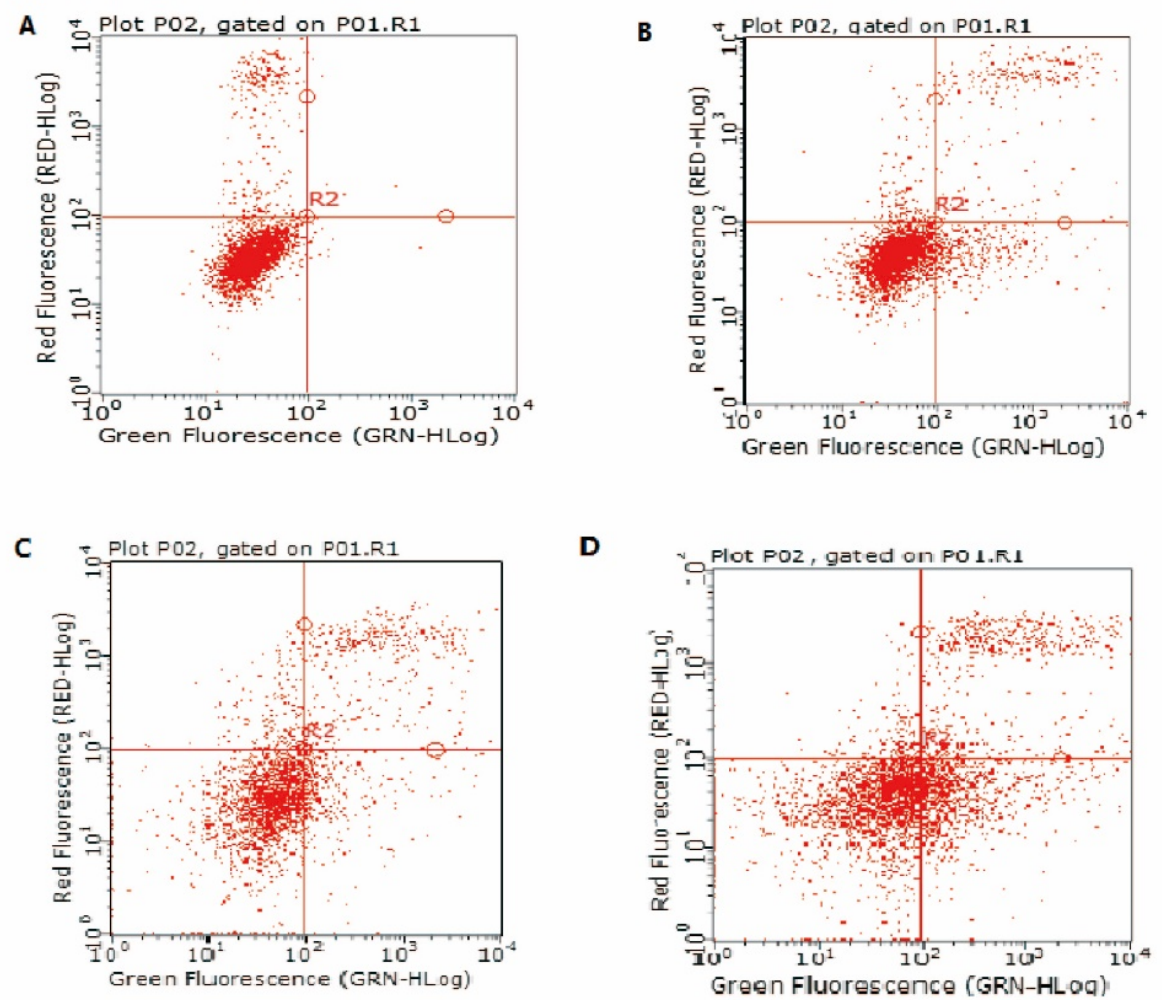

Figure 3. GY II enhances apoptosis of Hep-2 cells. Flow cytometry was conducted to determine the apoptosis of Hep-2 cells. (A) Control group ( $0 \%$ ); (B) $25 \%$ GYII-containing serum group; (C) 50\% GYII-containing serum group; (D) 100\% GYII-containing serum group

A

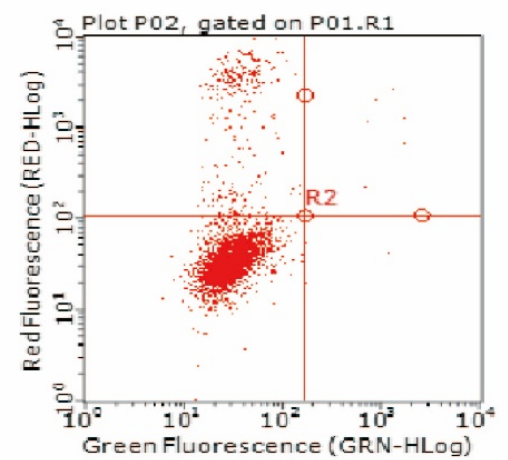

C

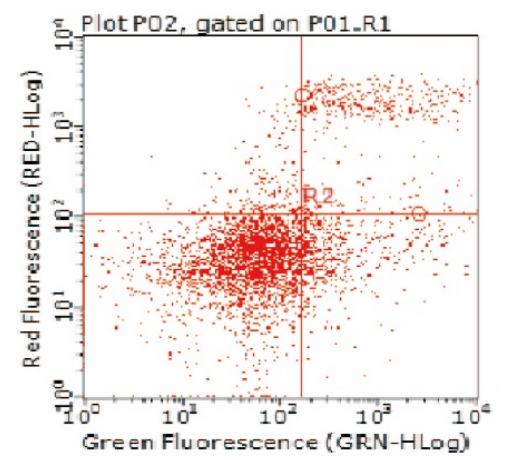

B

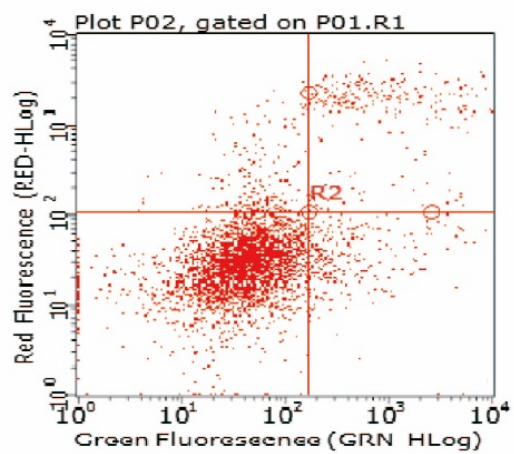

D

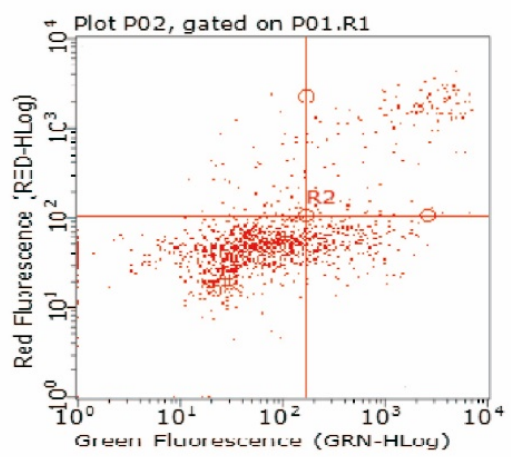

Figure 4. GY II enhances apoptosis of primary laryngeal carcinoma cells. Flow cytometry was conducted to determine the apoptosis of primary laryngeal carcinoma cells. (A) Control group (0\%); (B) 25\% GYII-containing serum group; (C) 50\% GYII-containing serum group; (D) $100 \%$ GYII-containing serum group 

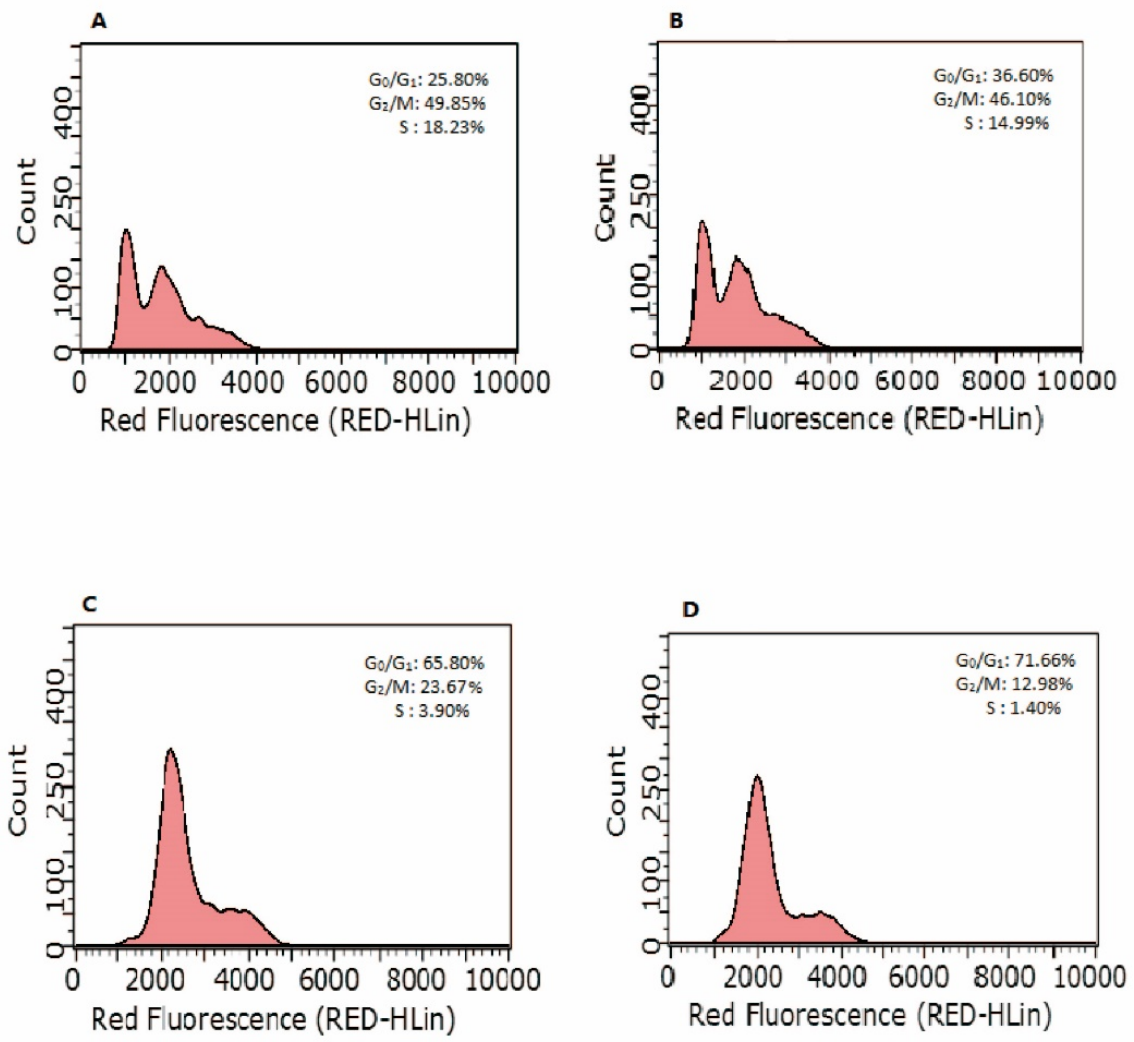

Figure 5. GY II treatment contributes to cell arrest of Hep-2 cells. At $24 \mathrm{~h}$ post-treatment, cells were stained with PI and cellular DNA content was quantified by Flow cytometry. The percentages of G0/G1, G2/M and S phase were presented. (A) Control group (0\%); (B) $25 \%$ GYII-containing serum group; (C) $50 \%$ GYII-containing serum group; (D) $100 \%$ GYIIcontaining serum group
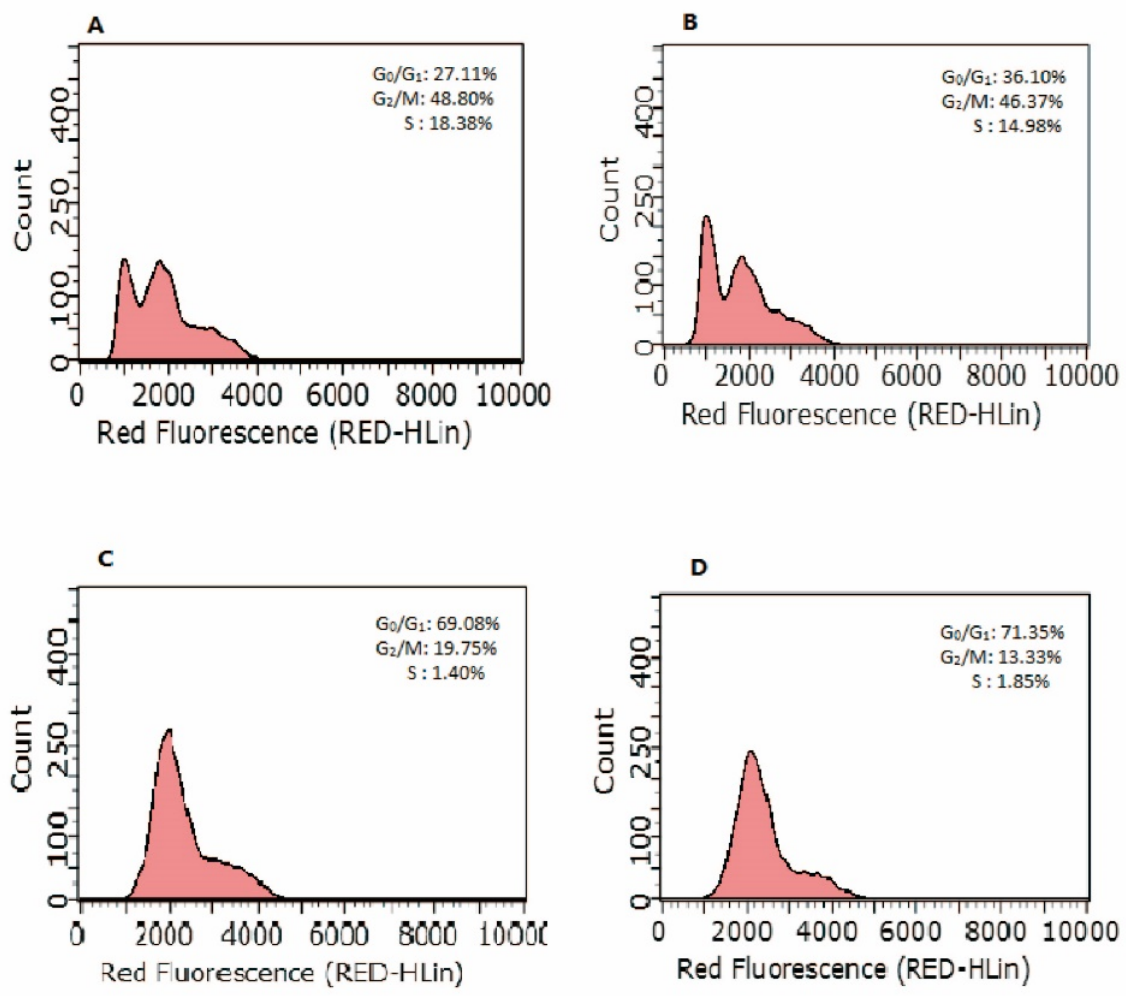

Figure 6. GY II treatment contributes to cell arrest of primary laryngeal carcinoma cells. At $24 \mathrm{~h}$ post-treatment, cells were stained with PI and cellular DNA content was quantified by Flow cytometry. The percentages of G0/G1, G2/M and S phase were presented. (A) Control group (0\%); (B) $25 \%$ GYII-containing serum group; (C) $50 \%$ GYII-containing serum group; (D) $100 \%$ GYII-containing serum group 
cancer cells and Hep-2 cells. Indeed, the inhibitory effects of GY II display in a dose-dependent manner. When concentration of GY II is $75 \%$, the inhibition rate of high dose GY II $(75 \%)$ is $54.4 \%\left(\mathrm{IC}_{50}=67.59\right.$ $\mathrm{mg} / \mathrm{ml})$ of primary laryngeal cancer cells and $55.3 \%\left(\mathrm{IC}_{50}=69.57 \mathrm{mg} /\right.$ $\mathrm{ml}$ ) of Hep-2 cells.

Regulating cell apoptosis and/or cell cycle has become the important strategy for the treatment of malignant tumors. Most TCM herbs have been shown to exhibit effects on cell apoptosis $[19,20]$. Our results indicate GYII is able to induce cell apoptosis and the effects display in a dose-dependent.

Overall, our research demonstrates that GYII inhibit cancer cell proliferation via arresting the cell cycle, the cell invasion and migration ability is also inhibited by GYII. Meanwhile, GYII can significantly induce cell apoptosis. Our findings have significant implications regarding understanding the mechanism and target of TCM herb GYII in term of tumor cure.

\section{Acknowledgement}

This work was supported by National Science Foundation of China (NO.81473499).

\section{References}

1. Jones TM, De M, Foran B, Harrington K, S Mortimore S, et al. (2016) Laryngeal cancer: United Kingdom National Multidisciplinary guidelines. J Laryngol Otol 130: S75-S82. [Crossref]

2. Klatka J, Grywalska E, Klatka M, Wasiak M, Andrzejczak A, et al. (2013) Expression of selected regulatory molecules on the CD83+ monocyte-derived dendritic cells generated from patients with laryngeal cancer and their clinical significance. Eur Arch Otorhinolaryngol 270: 2683-2693. [Crossref]

3. Jin, Huang WJ, Meng X, Yang F, Zheng YJ, et al. (2017) Chinese herbal medicine TangBi Formula treatment of patients with type 2 diabetic distal symmetric polyneuropathy disease: study protocol for a randomized controlled trial. Trials 18 : 631. [Crossref]

4. Aldini R, Budriesi R, Roda G, Micucci M, Ioan P, et al. (2012) Curcuma longa extract exerts a myorelaxant effect on the ileum and colon in a mouse experimental colitis model, independent of the anti-inflammatory effect. PloS one 7: e44650. [Crossref]

5. Hong SL, Lee GS, Syed Abdul Rahman SN, Ahmed Hamdi OA, Awang K, et al. (2014) Essential oil content of the rhizome of Curcuma purpurascens B1. (Temu Tis) and its antiproliferative effect on selected human carcinoma cell lines. ScientificWorldJournal: 397430. [Crossref]
6. Kang N, Cao SJ, Zhou Y, He H, Tasgiro SC, al. (2015) Inhibition of caspase-9 by oridonin, a diterpenoid isolated from Rabdosia rubescens, augments apoptosis in human laryngeal cancer cells. Int J Oncol 47: 2045-2056. [Crossref]

7. Shi Z, Song T, Wan Y, Xie J, Yan Y, et al. (2017) A systematic review and meta-analysis of traditional insect Chinese medicines combined chemotherapy for non-surgical hepatocellular carcinoma therapy. Sci Rep 7: 4355. [Crossref]

8. Jiao L, Dong C, Liu J, Zhang L, Xu J, et al. (2017) Effects of Chinese Medicine as Adjunct Medication for Adjuvant Chemotherapy Treatments of Non-Small Cell Lung Cancer Patients. Sci Rep 7: 46524. [Crossref]

9. Zhang Y, Zhang GL, Sun X, Cao KX, Shang YW, et al. (2017) Gubenyiliu II Inhibits Breast Tumor Growth and Metastasis Associated with Decreased Heparanase Expression and Phosphorylation of ERK and AKT Pathways. Molecules 22: E787. [Crossref]

10. Wang N, Feng Y, Cheung F, Wang X, Zhang Z, et al. (2015) A Chinese medicine formula Gegen Qinlian decoction suppresses expansion of human renal carcinoma with inhibition of matrix metalloproteinase-2. Integr Cancer Ther 14: 75-85. [Crossref]

11. Huang ST, Pang JH, Yang RC (2010) Anti-cancer effects of Phyllanthus urinaria and relevant mechanisms. Chang Gung Med J 33: 477-487. [Crossref]

12. Tian Y, Liu SY, Jiang WJ (2016) The Effects of Qizhenfuzheng Medical Soup combined with the Chemotherapies on the Treatment of Non-small Cell Lung Cancer Patients after Operation. Chinese Journal of Surgery of Integrated Traditional \& Western Medicine.

13. Shufeng AN, Shen Y, Zhang Y (2106) Clinical Observation on JianPi YiShen Tang Combined with NP Regimen in Treating Advanced Non-small Cell Lung Cancer. $J$ Tradit Chin Med 29:79-82.

14. Zhang GL, Wang XM, Ping LI (2007) Inhibitory effect of Gubenyiliu Formula II and its combinative effect with chemotherapeutants on mouse Lewis lung carcinoma. Journal of Beijing University of Traditional Chinese Medicine.

15. Lin PC, Chiou TW, Harn HJ (2011) An Evidence-based Perspective of Angelica Sinensis (Chinese Angelica) for Cancer Patients. Evidence-based Anticancer Materia Medica: $131-153$.

16. Liu Y, Roy SS, Nebie RH, Zhang Y, Nair MG (2013) Functional food quality of Curcuma caesia, Curcuma zedoaria and Curcuma aeruginosa endemic to Northeastern India. Plant Foods Hum Nutr 68: 72-77. [Crossref]

17. Lin YR, Wu MY, Chiang JH, Yen HR, Yang ST, et al. (2017) The utilization of traditional Chinese medicine in patients with dysfunctional uterine bleeding in Taiwan: a nationwide population-based study. BMC Complement Altern Med 17: 427. [Crossref]

18. Zhang Q, Chi HC, Jie YU (2007) Clinical Study of Guben Yiliu? Combined with Chemicals Arterial Perfusion for Advanced Hepatoma of 58 Cases. J Tradit Chin Med.

19. Zendedel E, Butler AE, Atkin SL, Sahebkar A, et al. (2018) Impact of curcumin on sirtuins: A review. J Cell Biochem 119: 10291-10300. [Crossref]

20. Lin L, Li L, Chen X, Zeng B, Lin T (2018) Preliminary evaluation of the potential role of beta-elemene in reversing erlotinib-resistant human NSCLC A549/ER cells. Oncology letters 16: 3380-3388. [Crossref]

Copyright: (C2018 Bai Y. This is an open-access article distributed under the terms of the Creative Commons Attribution License, which permits unrestricted use, distribution, and reproduction in any medium, provided the original author and source are credited. 